\title{
Paste deposition over an existing subaqueous slurry deposit of high sulphide content tailings - the Neves Corvo experience
}

\author{
R. Lopes Golder Associates Brasil Consultoria e Projetos Ltda., Brazil \\ R. Bahia Golder Associates Portugal Unipessoal Lda., Portugal \\ M. Jefferies Golder Associates Ltd., Canada \\ M. Oliveira Somincor, Portugal
}

\begin{abstract}
Neves Corvo is a world-class underground copper-zinc mine located in the south of Portugal. The mine has been in operation since 1988 by Somincor (Sociedade Mineira de Neves-Corvo SA), a wholly-owned subsidiary of Lundin Mining Corporation from Canada.

The pyritic tailings produced have a very high acid generation potential and until 2010 had been placed subaqueously in the Barragem Cerro do Lobo (BCL), a large tailings pond (190 ha) created by a rockfill dam, $42 \mathrm{~m}$ high, across a natural water course. That disposal system provided safe and reliable storage of the reactive tailings. However, by 2001 Somincor realised that the remaining subaqueous deposition capacity was limited and that an alternative site or other deposition methods would be required at this site. Following nine years of studies and evaluation of various alternatives Somincor decided to extend the life of the existing facility, by switching in late 2010 to using subaerial paste/thickened tailings deposition over the existing subaqueous slurry deposit. This approach provides the required storage volume for Somincor's 2005 Life of Mine Plan, and allows maintaining the existing perimeter dam at its current elevation, and facilitates site closure.
\end{abstract}

This paper presents the results of the first two years of operation of the paste production plant and depositional performance of the first two to four metres of paste/thickened tailings over the very loose subaqueous deposit. Routine monitoring data reported includes records of produced paste/thickened tailings densities, yield stress, particle size distribution (PSD), and average specific gravity (SG) of solids. Settlement, deposition beach slopes and piezometric levels in the paste and underlying subaqueous deposit are also routinely monitored.

In addition, in 2012 a campaign of Cone Penetration Test Undrained (CPTu) testing and collection of piston samples was carried out to provide in situ strength and permeability data as well as evaluation of the state parameter of the deposited tailings. The 2012 CPTu data is being used for ongoing assessment of the dynamic stability of planned deposition for the next two years. This type of data and a planned special laboratory testing program will be used to calibrate a model of the evolution of the void ratio of the deposit as a function of time and of additional deposition loads. This model will guide the design of the final deposition landform.

The environmental component of the deposition monitoring program includes the monitoring of the $\mathrm{pH}$ profile of the top one metre of tailings left exposed and allowed to dry as a result of the sequential rotation of tailings discharge.

\section{Introduction}

Neves Corvo is the largest mine in Portugal, located near Castro Verde, some $220 \mathrm{~km}$ south of Lisbon (Figure 1), on the western edge of the Iberian Pyritic Belt. The local climate is semi-arid, with average 
annual precipitation of $484 \mathrm{~mm}$, mostly occurring between October and April, and evaporation of about $1,313 \mathrm{~mm}$ per year.

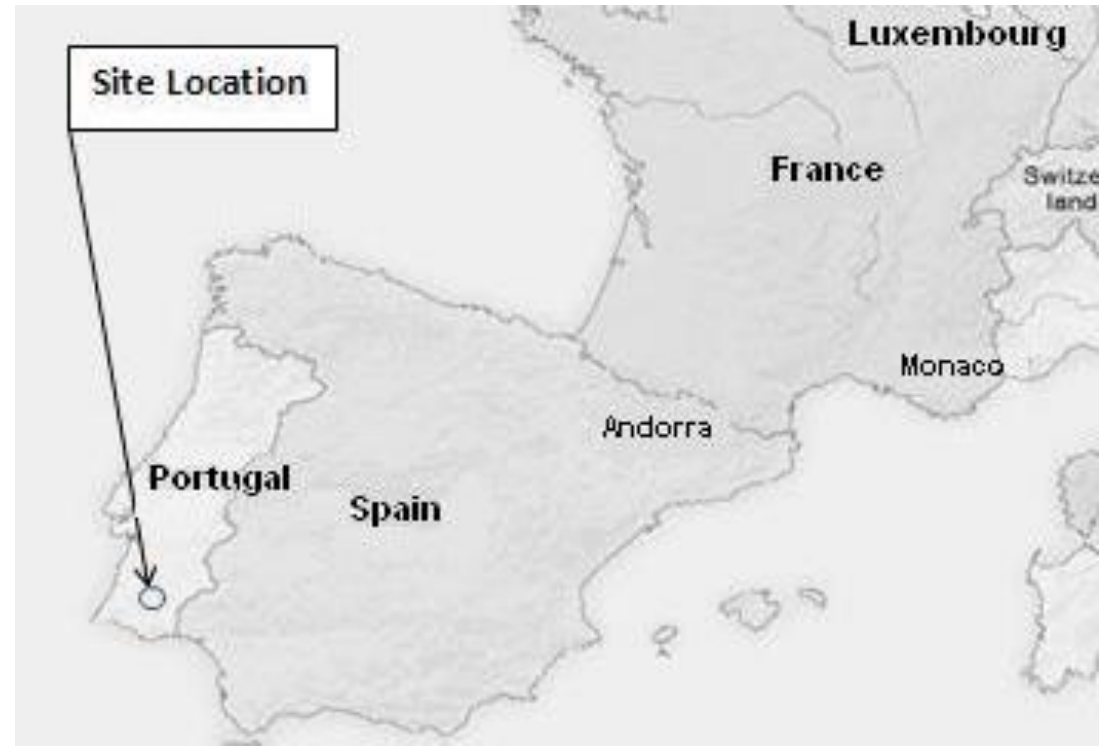

\section{Figure 1 Site location}

The underground mine has been operating since 1988 by Somincor (Sociedade Mineira de Neves-Corvo SA), a wholly-owned subsidiary of Lundin Mining Corporation from Canada.

The tailings produced in the copper and zinc plants are sulphide-rich, comprising 40 to $50 \%$ pyrite (FeS2) by mass. They have very high net acid generating potential, with the acid potential (AP) between approximately 700 and $800 \mathrm{~kg} \mathrm{CaCO}_{3} /$ ton and the neutralising potential (NP) averaging $30 \mathrm{~kg} \mathrm{CaCO} /$ ton.

Tailings have been disposed since the start of the mine operations in the "Instalação de Resíduos de Cerro do Lobo" (IRCL) tailings management facility (TMF) using subaqueous deposition methods to control oxidation of the sulphides.

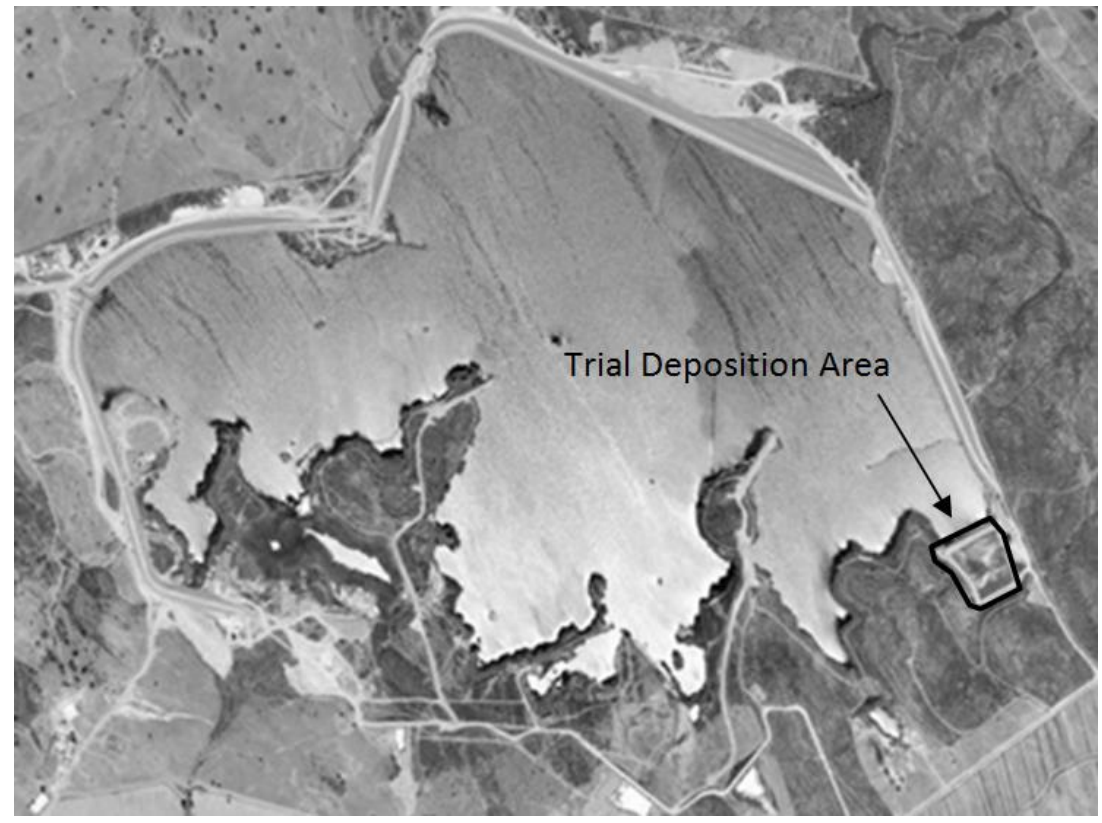

\section{Figure 2 Neves Corvo TMF - year 2006}

Somincor's 2005 Life of Mine (LOM) Plan envisaged ore production rates of $1.5 \times 10^{6}$ to $2.5 \times 10^{6}$ megagrams $(\mathrm{Mg})$ per annum and at these production rates the subaqueous deposition capacity of the IRCL 
would be exhausted by 2011. Therefore in 2005 Somincor commissioned Golder Associates to do a feasibility study focused on providing the required 2005 LOM Plan capacity through use of thickened/paste tailings technology.

The feasibility study included the installation in 2005 of a $20 \mathrm{~m}^{3} / \mathrm{hr}$ paste pilot plant and one hectare trial deposition area at the location shown on Figure 2. The trial deposition was completed between April and November 2005. Results of the trial deposition were published most recently at the 2009 ICARD conference in Sweden (Verburg et al., 2009).

The main elements of the 2005 LOM expansion design are as follows (Oliveira et al., 2011):

- Deposition of thickened tailings/paste sequentially into 15 cells, each with approximately six months to one year capacity.

- The cells are separated by mine waste rock dykes, which include a co-deposition element in the expansion design.

- The sequential cell filling and placement of final cover allows for progressive site restoration and better control of acid generation and runoff during the operating years.

- Modelling of post-closure drawdown of the water table in the deposit, and predictions of long term environmental performances indicate that the use of a common soil cover (similar to regional surface soils) would be best in order to promote a high degree of saturation and low oxidation rates in the deposit (Junqueira et al., 2009).

A plan view and cross section of the proposed completed facility, as per the 2005 LOM Plan, are given in Figure 3. 

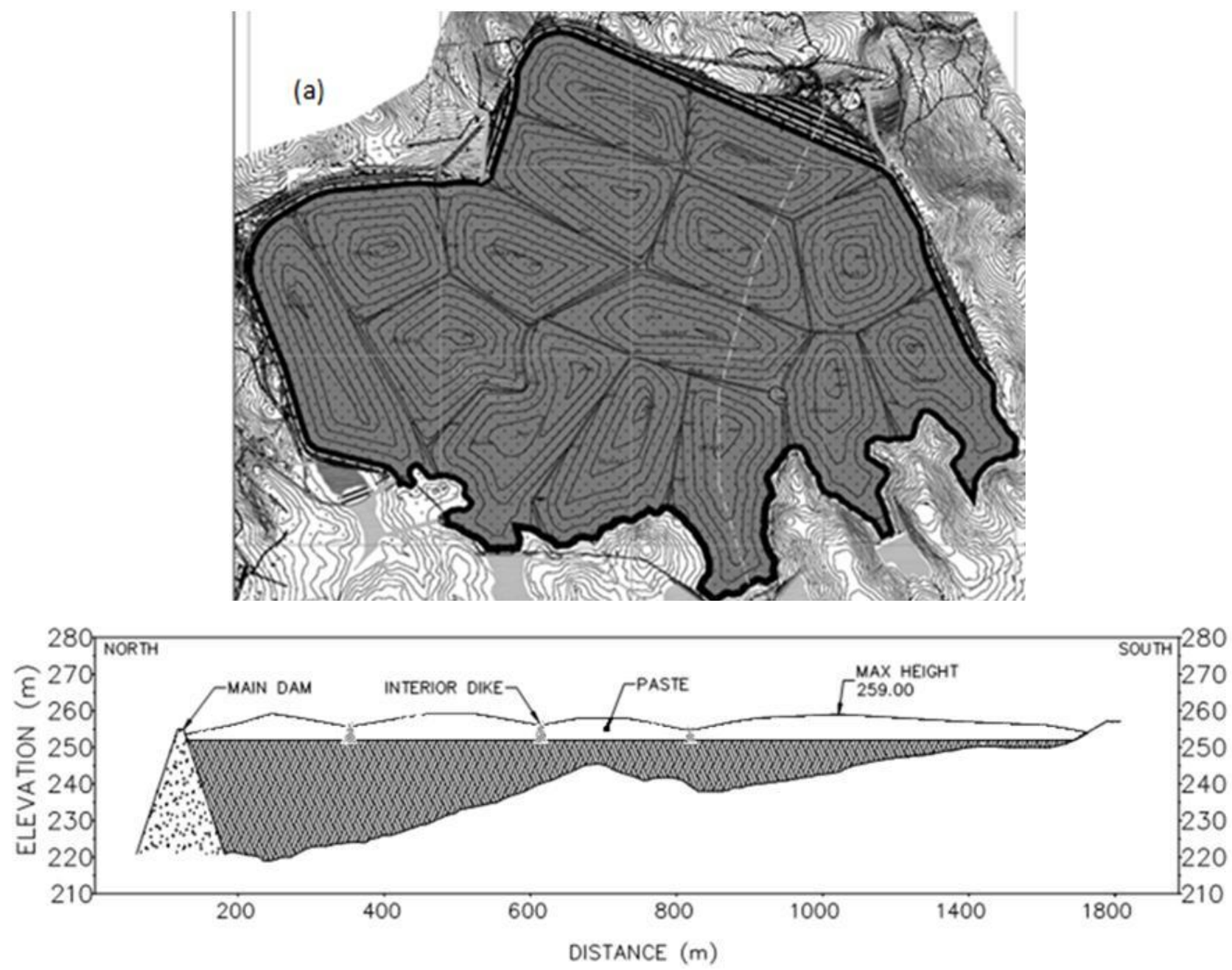

Figure 32005 LOM paste deposit design (top) plan view (bottom) cross section

A description and discussion of the challenges encountered during the first two years of operation of the paste deposition project (November 2010 to November 2012) is given in the following sections of this paper.

\section{Variability of tailings feed to the TMF thickening plant}

One of the most challenging issues in the Neves Corvo TMF thickening or paste plant operation is the time variability of mass flow rate and physical properties of the tailings.

The primary factor in this time variability of mass flow rate and physical properties is the existence of an underground paste backfill plant upstream of the TMF paste plant. The paste backfill plant includes cyclones and filters which take in a variable fraction of the total tailings produced at the mill, when backfill is required underground. Therefore depending on whether the backfill plant is operating or not, the tailings feed to the TMF paste plant are referred as 'backfill overflow tailings' or 'total tailings', respectively.

\subsection{Time variability of mass flow to the paste plant}

Figure 4 shows records of mass flow of the separate types of tailings feed (total versus backfill overflow) to the TMF paste plant, obtained by continuous reading by a gamma densometer. 

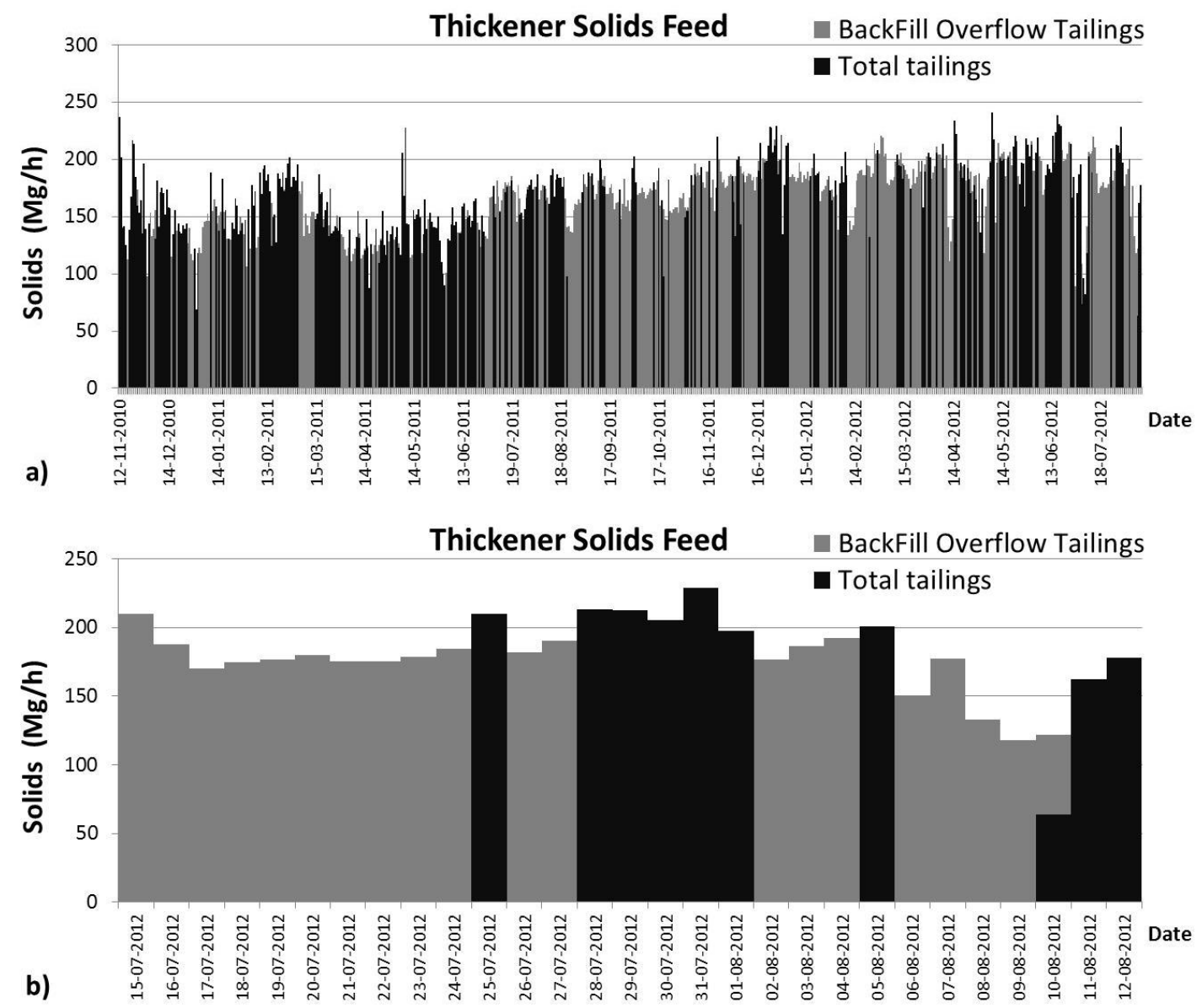

Figure 4 Daily thickener solids feed (a) 21 month period, and (b) 1 month period

The graphs show that the feed consists more frequently of backfill overflow tailings than of total tailings and that daily mass flow rates can vary significantly (e.g. from 120 to $225 \mathrm{Mg} / \mathrm{hr}$ ).

\subsection{Time variability of physical properties of feed to the paste plant}

The TMF Paste Plant uses laser equipment (ciclosizer) for monitoring on a periodic basis (eight hour interval) the PSD of the tailings solids entering the plant. Figure 5 shows the results of PSD monitoring over a four month period. 

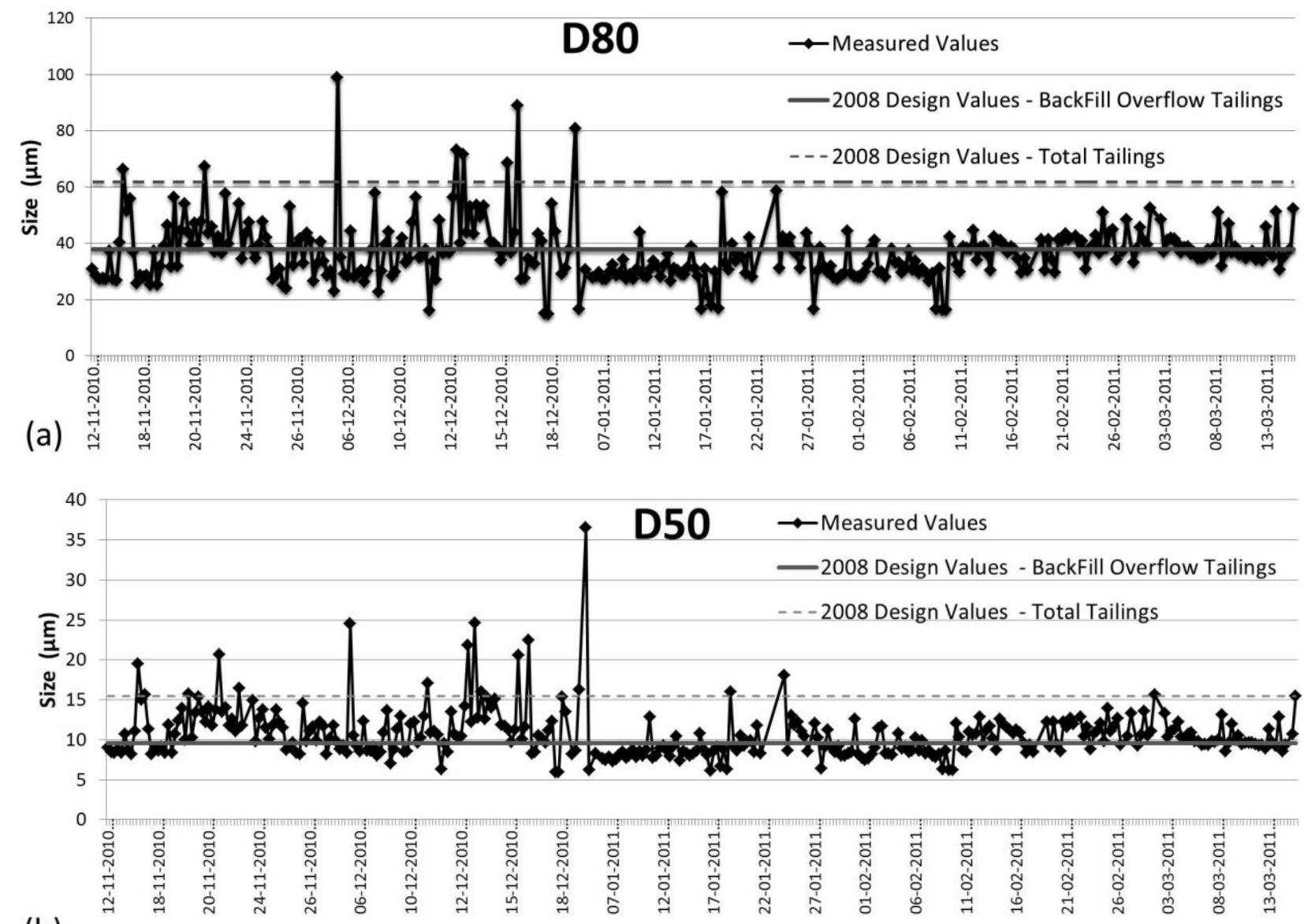

(b)

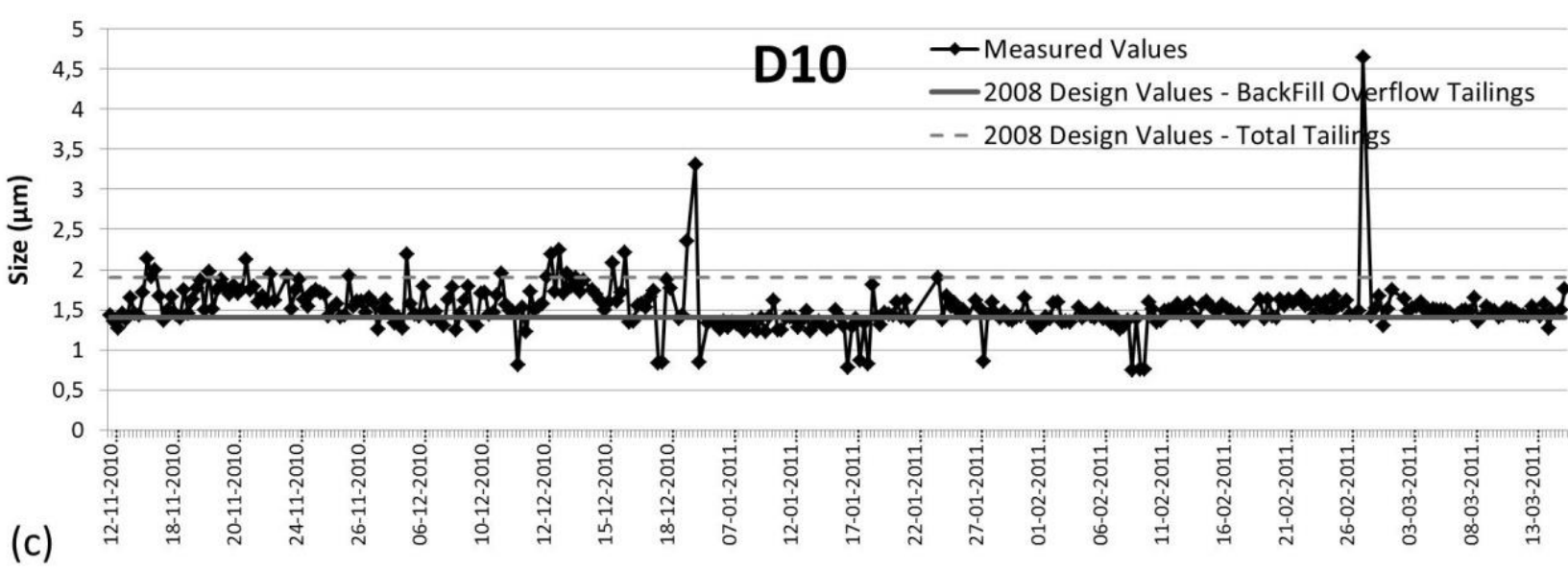

Figure 5 Time variation of PSD (a) D80; (b) D50; (c) D10

The Figure 5 graphs show that there are significant time variations in PSD of the feed, and that the feed has been generally finer than the paste plant design values, which were established on bulk samples of both tailings types, collected in 2008. On average the feed PSD has been generally close to the backfill overflow tailings design values.

A number of samples of deposited tailings produced in 2011 were tested for average SG of the solid particles. Those results compared with the design supplied samples of 2008 show a reduction on the average SG of the tailings when compared with material processed in 2008. The results are shown in Figure 6. 


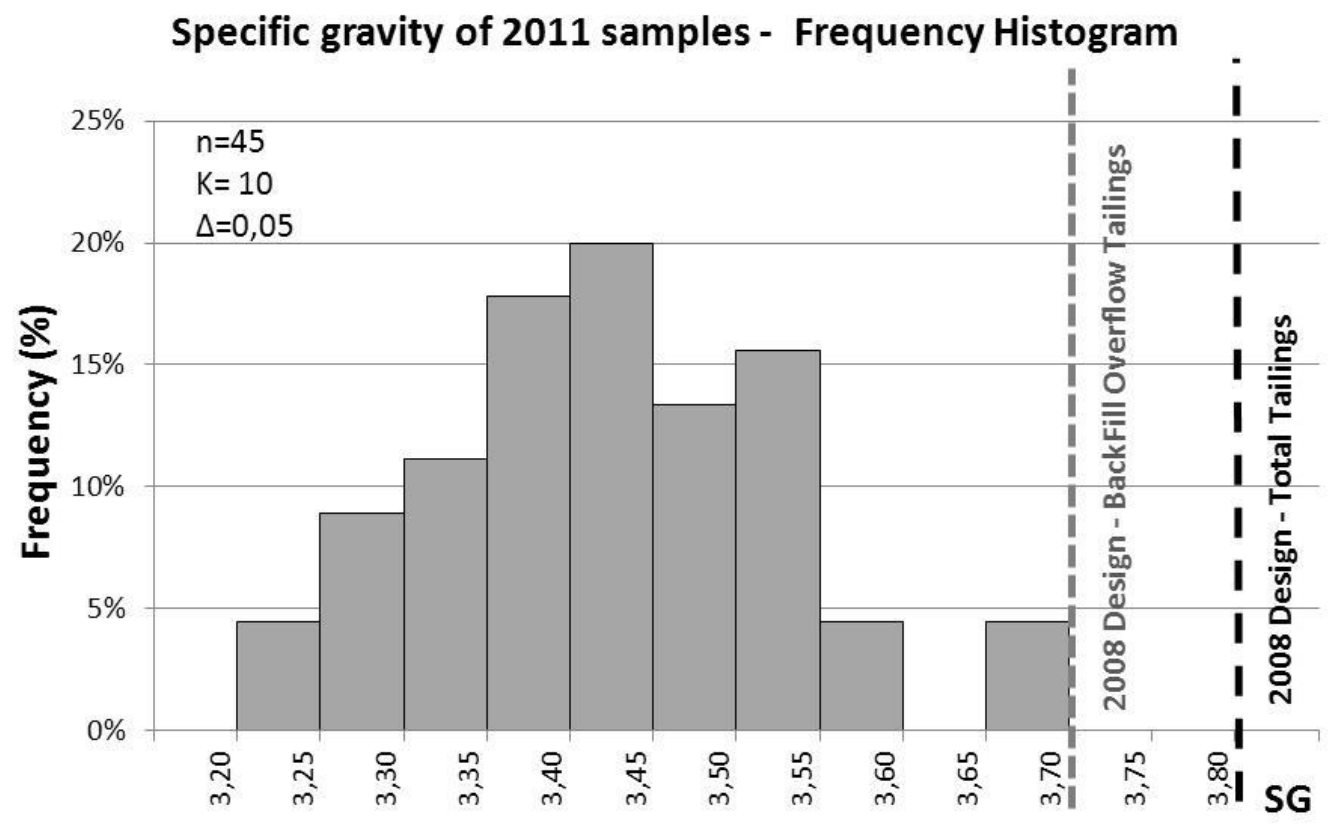

\section{Figure 62011 tailings samples SG}

It is believed that the dominant processing of copper ores in the 2011-2012 period versus zinc ores in the 2005-2008 design period accounts for the generally lower average SG of the feed to the TMF paste plant. However the normal distribution of the 2011-2012 values suggests also that there are real differences in the average SG of the particles due to different pyrite content of the 30-40 g specimens used in picnometer testing for SG determination.

\subsection{Effects of variability of physical properties of feed on tailings rheology}

Given the above noted variability of feed characteristics, verification of effects of such variations on rheological behaviour of the tailings material was performed through the conventional determination of yield stress versus per cent solids of aqueous mixes of a 2012 tailings sample. The results are given in Figure 7.

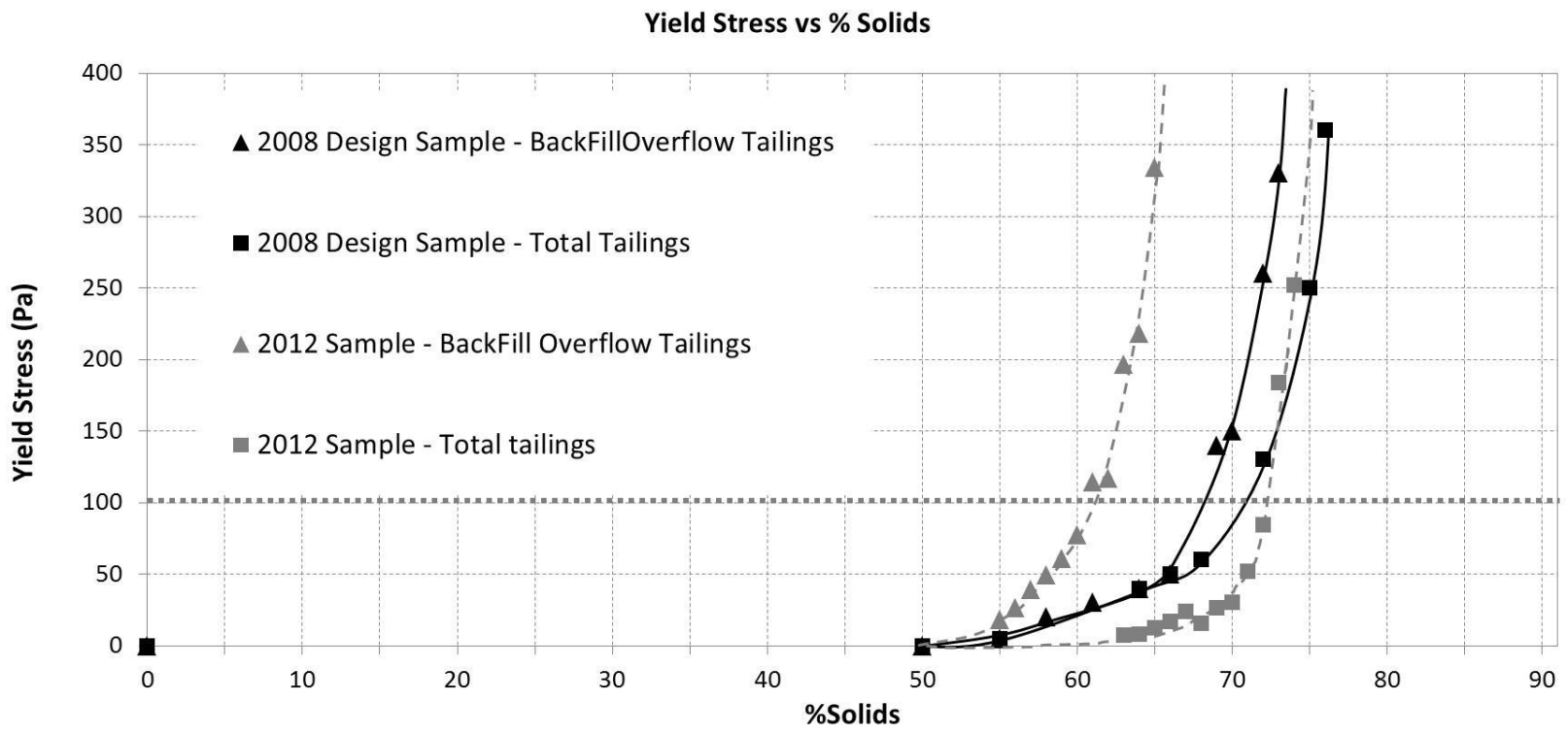

Figure 7 Yield stress versus \% solids 
The results show that there is a remarkable sensitivity of the tailings rheology to the PSD and SG characteristics of the two samples. The target per cent solids to achieve 100 Pa yield stress ('paste' consistency) ranges from about $62-72 \%$ based on these tests. It is therefore suggested that this variable nature of the tailings feed has significant effect on the paste plant performance.

\section{TMF paste plant performance}

\subsection{Homogenising efficiency of deep cone thickeners}

Given the observed time variability of the feed, an investigation of the homogenising efficiency of the TMF paste plant process was performed, consisting of taking samples of thickener feed and underflow over a period of one month. The PSD of the samples were determined and are shown in Figure 8.

\section{Particle Size Distribution - Thickener Underflow Vs Thickener Feed}

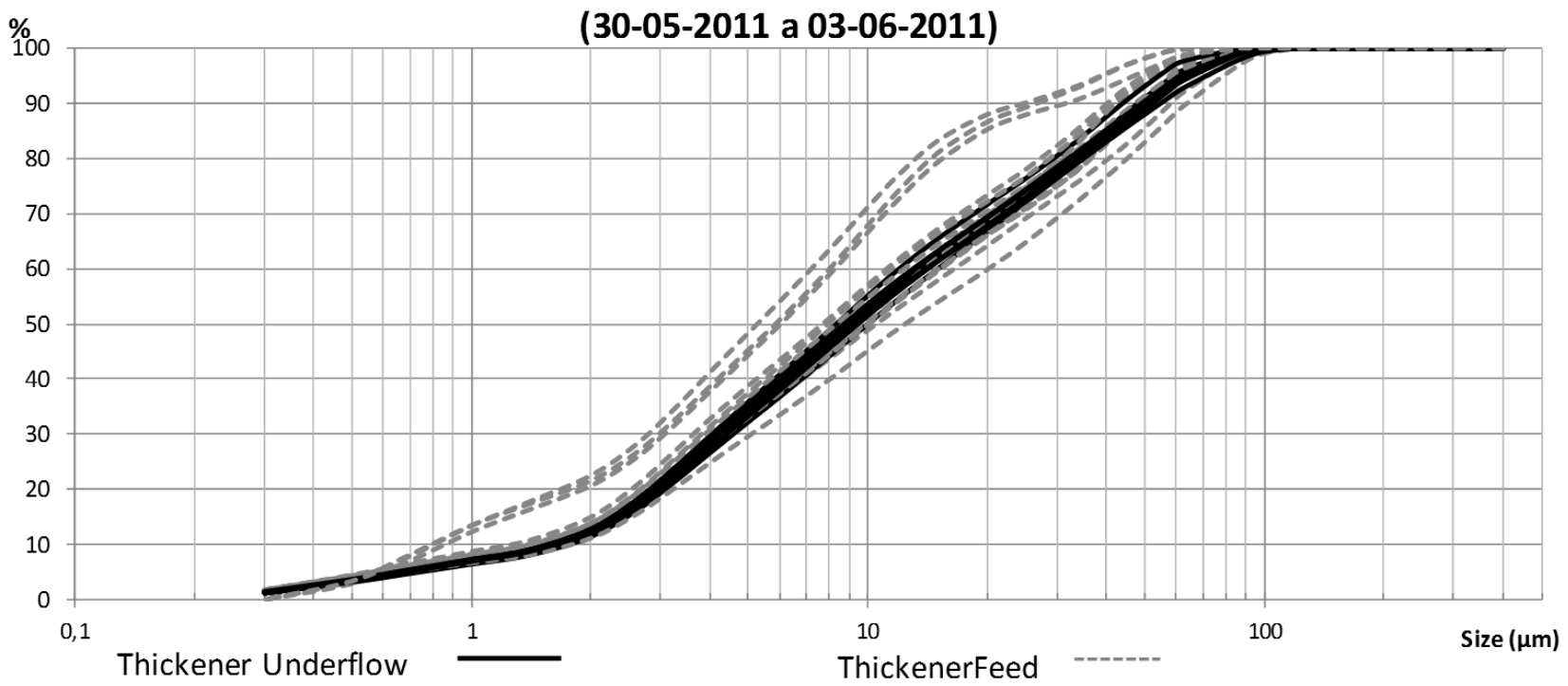

Figure 8 PSD of thickener feed versus thickener underflow

The above results show that the deep cone thickener (DCT), which has an average residence time of seven to ten hours, has a significant homogenising effect on the physical properties of its underflow solids.

\subsection{Time variability and factors influencing degree of thickening achieved}

Density (defined here as mass of solids per $\mathrm{m}^{3}$ of paste) is a commonly used method of monitoring thickening performance of a plant. The TMF paste plant is equipped with a gamma densometer which measures the mass flow of tailings in the thickener underflow. Figure 9 below shows a graph which reflects the time variability of thickening achieved by the TMF paste plant. 


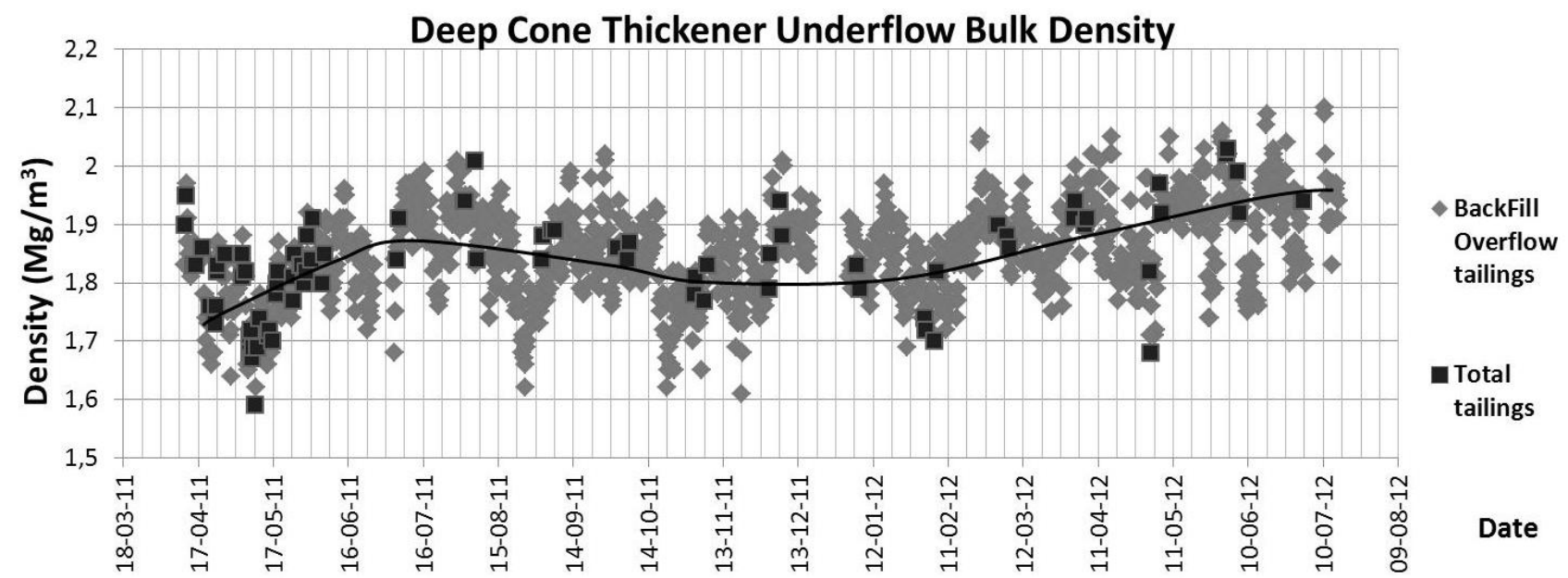

Figure 9 Variation of thickened tailings bulk density with time

The average line through the graph indicates the general trend: an initial operators' learning period with lower performance, then a stabilising trend, followed by an improvement to a higher level in February 2012 when some problems with flocculent control were resolved.

A similar trend is observed by the applied torque in the raker arm of the DCT, as illustrated in Figure 10.

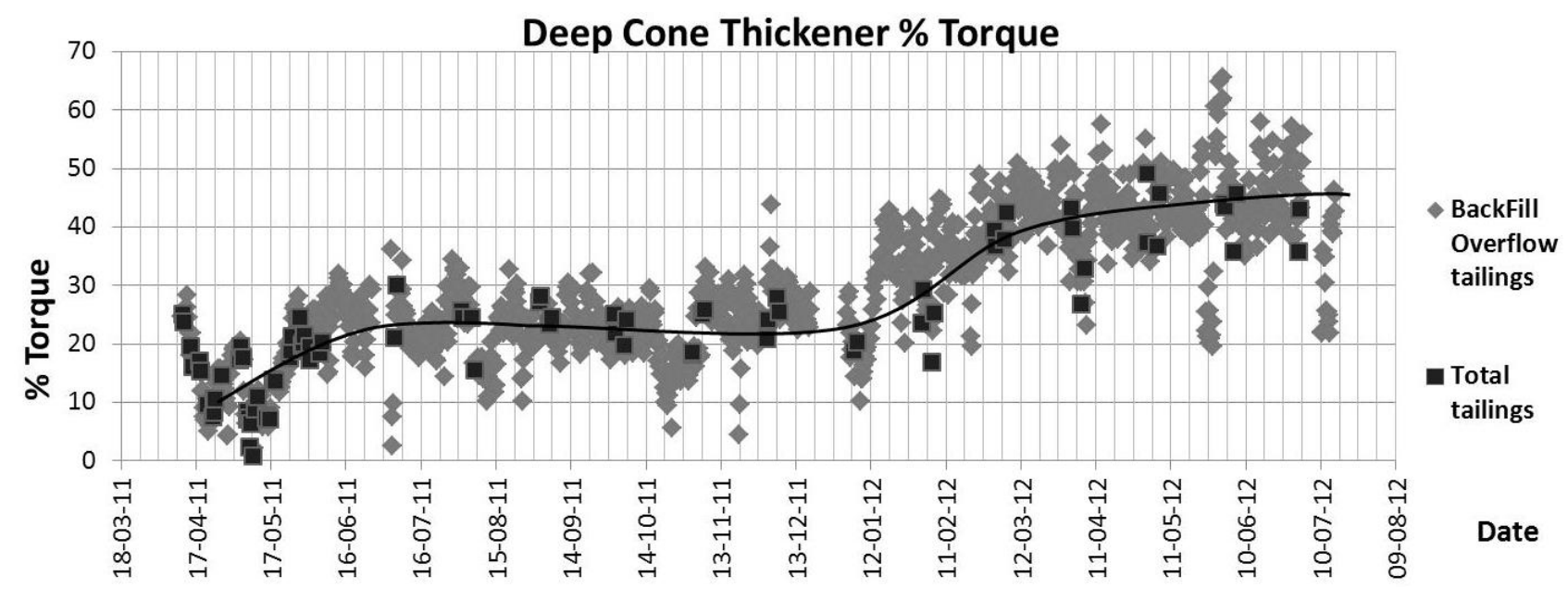

Figure 10 Variation of \% torque of the DCT with time

A more direct measure of degree of tailings thickening is yield stress. Routine daily monitoring of yield stress of samples of DCT underflow was performed using the 50 cent rheometer (Roussel and Coussot, 2004). The results of such measurements over time are given in Figure 11, and show a trend similar to the two previous parameters (density and torque). Note that after February 2012 the average yield stress of the DCT underflow is generally above $100 \mathrm{~Pa}$, which is indicative of 'paste' consistency. 


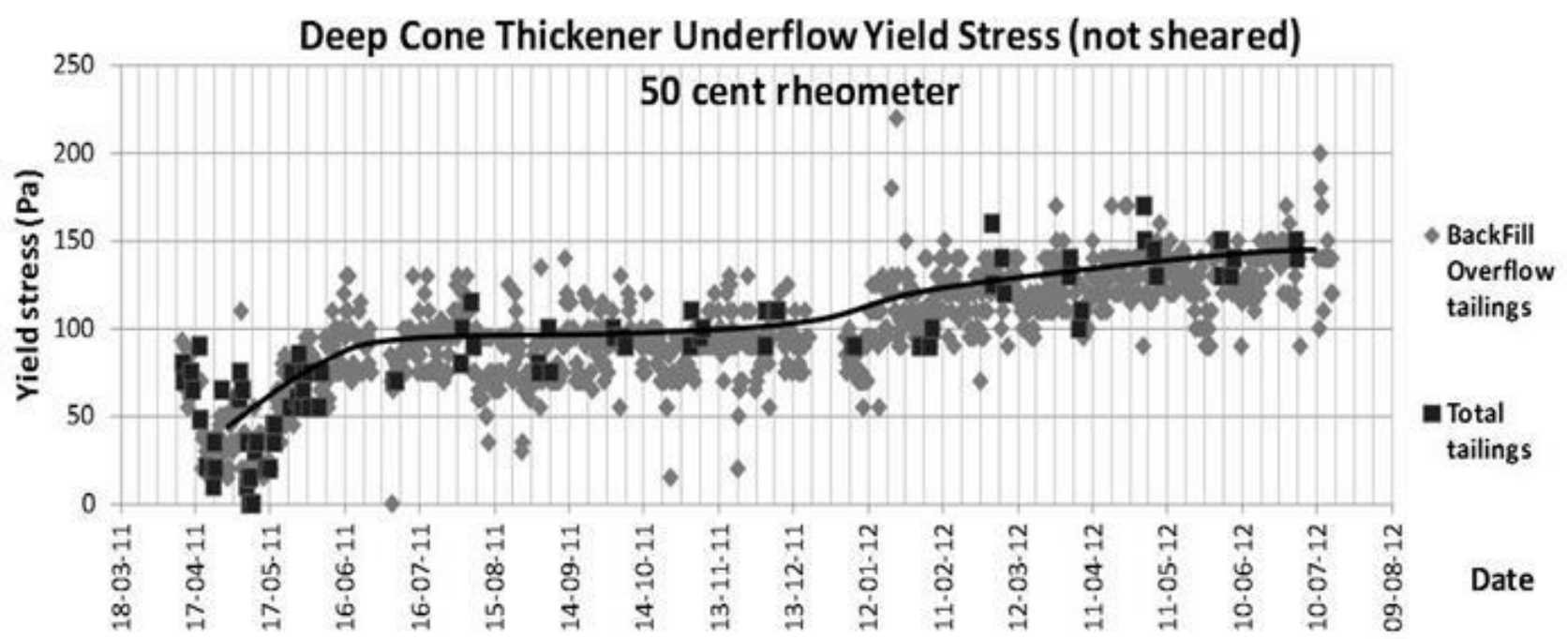

Figure 11 Variation of DCT underflow (not sheared) yield stress with time

It is recognised that paste is sheared in the process of pumping and transportation along pipelines, resulting in a lower yield stress product discharged into the deposition area. In order to investigate this factor, more recent samples on the DCT underflow were taken after the centrifugal pump - which feeds the displacement pump. The yield stress results of those samples are given in Figure 12. These tests were performed with a standard calibrated rheometer (Brookfield YR-1) during a two day working journey.

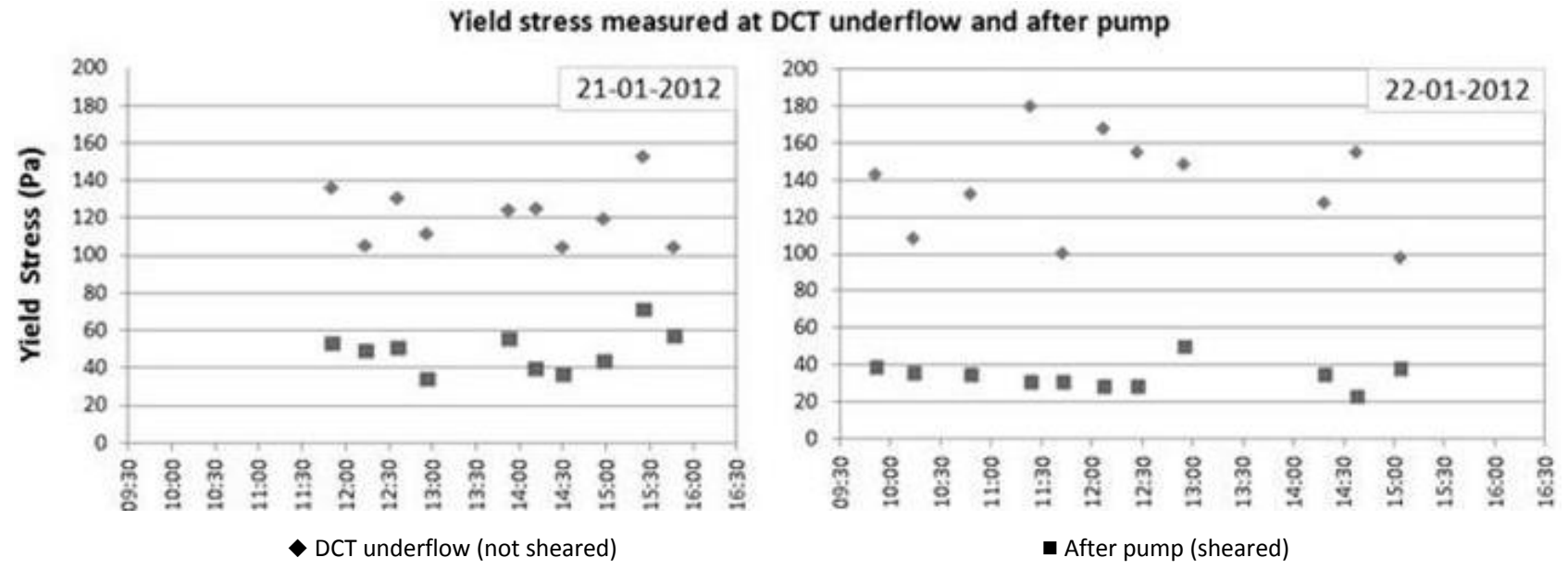

Figure 12 Variation of yield stress of not sheared and sheared paste - two day period

\section{$4 \quad$ TMF deposition monitoring}

\subsection{Discharge conditions and non-segregating behaviour}

As can be inferred from Figure 12 the thickened tailings are being discharged into the deposition cells at yield stresses generally in the range of 30-60 Pa. Visual observation of discharge at the site shows that the lower yield stress (lower consistency) tailings tend to flow in a preferential direction as slurries do, whereas the thicker tailings spread out more symmetrically/conically and achieve steeper beach slopes.

Due to the occurrence of higher production rates than the TMF paste plant was designed for in the period of November 2010 to September 2012 it became necessary to continue to deposit a fraction of the produced tailings subaerially as slurry. This afforded a comparison of in situ PSD of the thickened and nonthickened tailings. Figures 13 and 14 below illustrate the non-segregating behaviour of the thickened tailings (Figure 14) in comparison with the slurry tailings (Figure 13). 


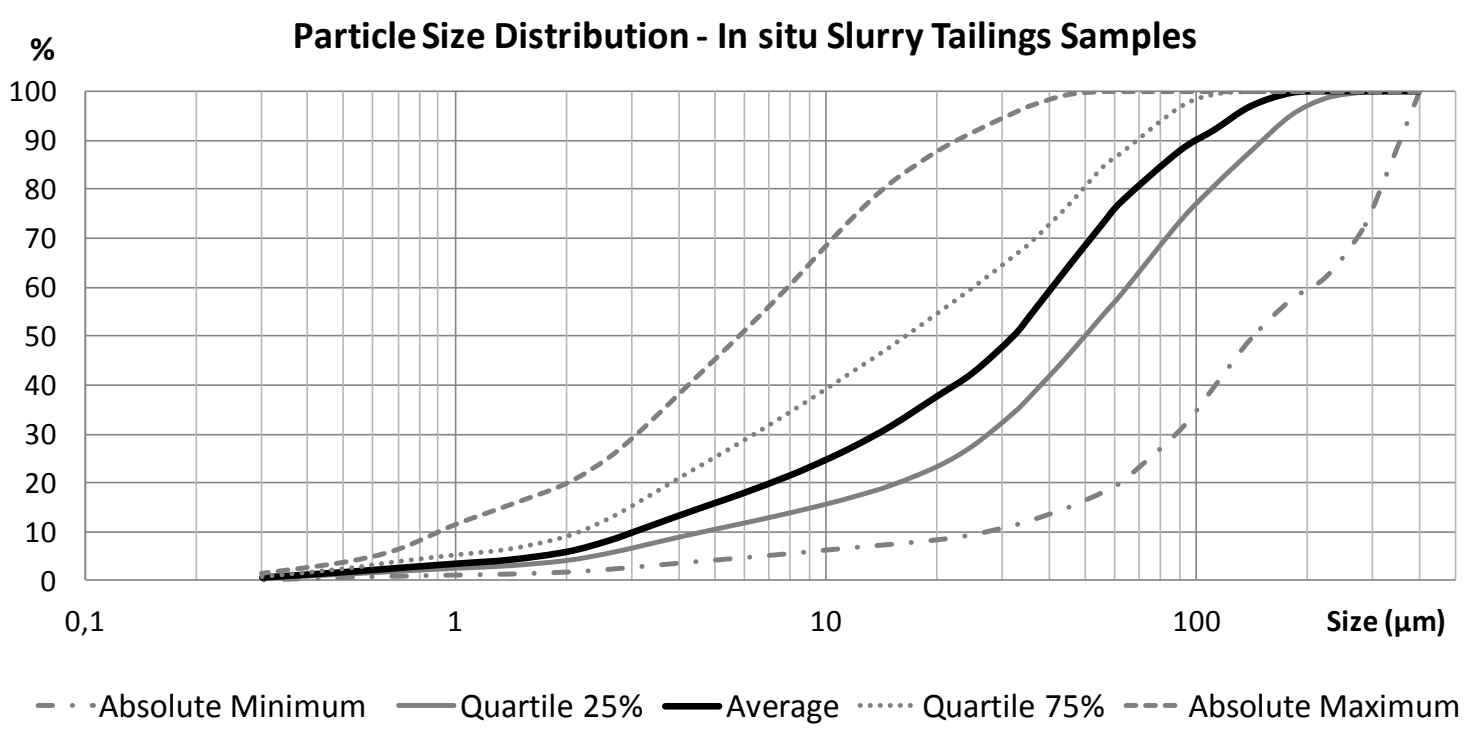

\section{Figure 13 PSD of in situ slurry tailings samples}

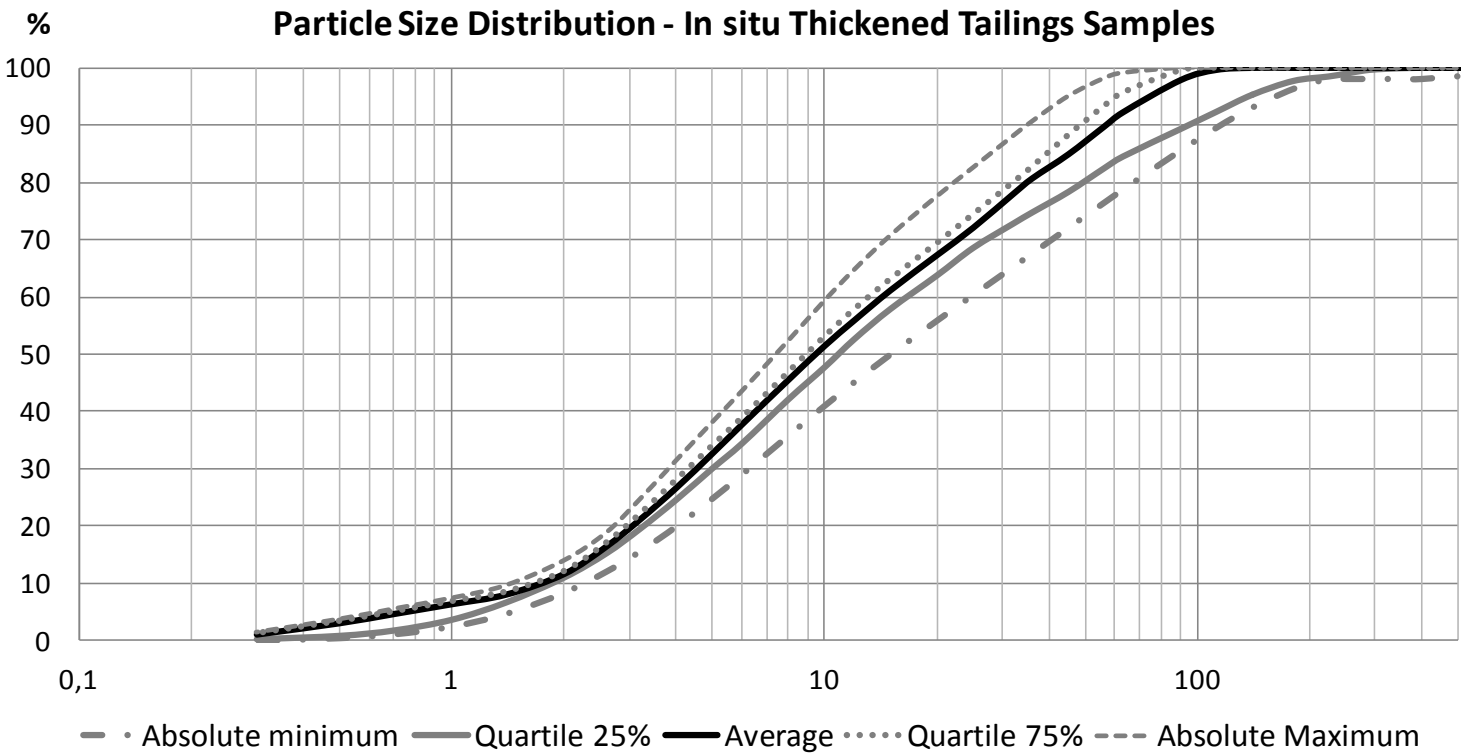

Figure 14 PSD of in situ thickened tailings samples

\subsection{Deposition beach slopes}

The angle of repose of discharged tailings, also referred as the beach slope (Li et al., 2009), depends on a number of factors including but not limited to:

- the angle of the pre-existing slope and its pore pressure conditions

- the yield stress of the discharged tailings

- local climatic conditions (rain, wind, dry hot weather, etc.)

- the discharge rate and run-out distance available for each layer.

The cell deposition system adopted under the 2005 LOM design allows runout distances from discharge points along the centre of each cell of 120-200 m, and layers of generally 30-50 cm thickness. In addition the existence of very loose slurry tails under $10-40 \mathrm{~cm}$ of ponded water provided a unique lower boundary condition for the thickened tailings deposition to date. In fact the surface of the deposit was too soft and inaccessible to foot traffic until about $1.5 \mathrm{~m}$ of thickened/paste tailings had accumulated and had been 
cyclically exposed to drying from the November 2010 deposition start up through the entire summer of 2011. This is in contrast with experience at Bulyanhulu (Theriault et al., 2003) and at Musselwhite (Kam et al., 2011) , where access to foot traffic was attainable within a few days and two weeks, respectively.

In the authors' opinion the initial deposition into ponded water and upward reporting consolidation water from underlying very loose unconsolidated subaqueous tailings played a large role in the low rate of strength gain of the first $1.5 \mathrm{~m}$ of thickened tailings. Tailings and paste consolidation is monitored with push in type vibrating wire piezometers; these piezometers show ongoing consolidation of the underlying subaqueous slurry and related upward flow of water. Additional discussion of the consolidation and strength gain aspects is provided in the following section of this paper.

Figure 15 illustrates the evolution of beach slopes from a selected central discharge point.
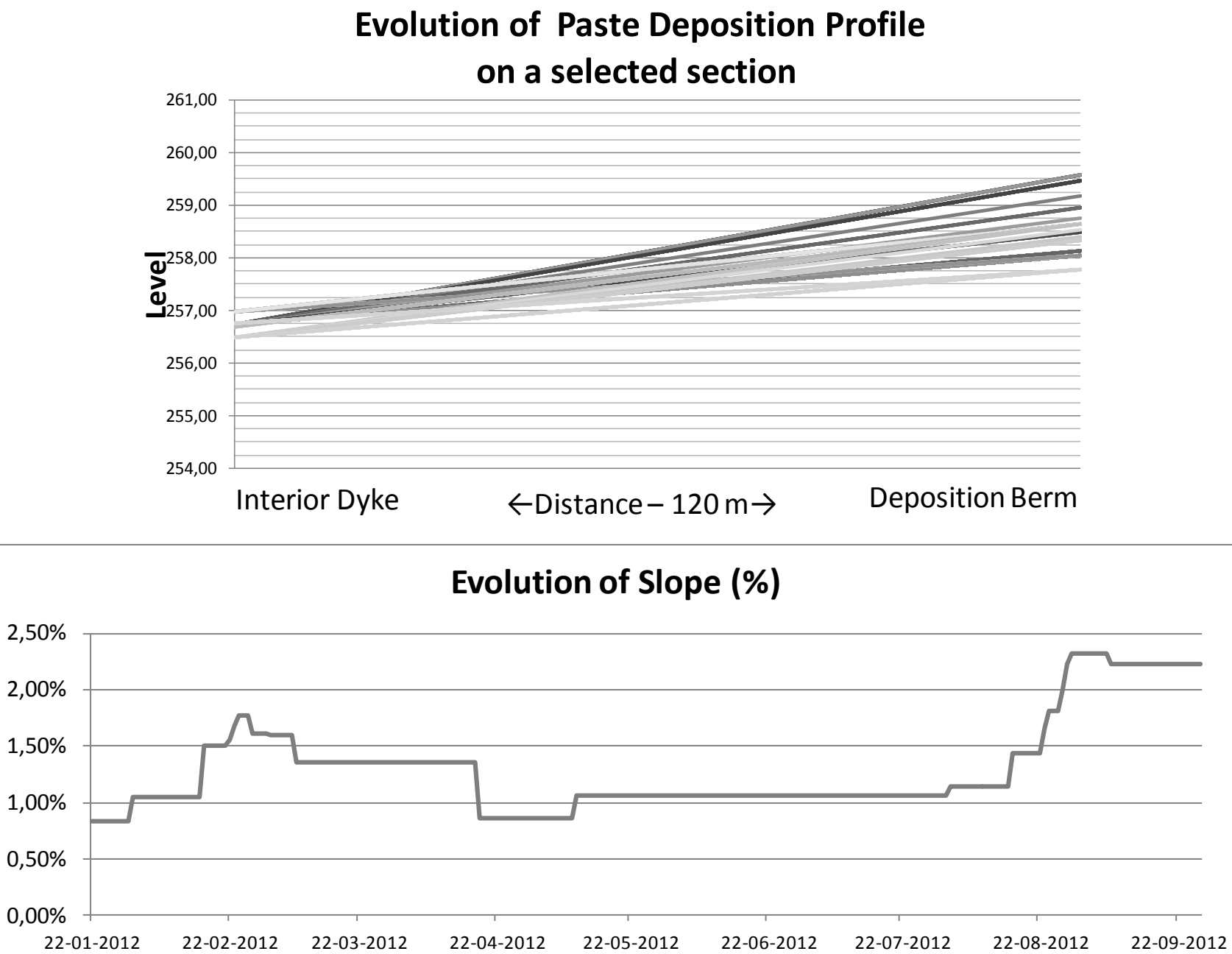

\section{Figure 15 Evolution of deposition profile - gain and loss of beach slope in time}

This profile corresponds to a transverse profile of deposition in the upstream portion of a cell. The deposition plan calls for developing a general gradient from the interior (upstream) of each cell to the periphery, for drainage purposes. The trend in evolution of beach slope in this case suggests an improvement in degree of thickening and drying conditions in the summer of 2012. Profiles in the downstream area of cells however show flatter beaches, likely as a result of accumulation of the lower yield stress (thinner) tailings in the downstream area of cells.

It should be noted that the 2005 LOM filling scheme is not driven by developing a conical deposit and maximising beach slopes. Rather, the objective is to provide the desired capacity with minimal stacking above the existing perimeter dams and maintain control on oxidation of the subaerial thickened/paste surfaces. 


\subsection{In situ consolidation and drying effects}

As noted, physical access to the surface of the deposit was delayed until late summer 2011, due to the initial discharge of tailings into ponded water, coupled with upward flow of pore water from consolidation of very loose subaqueous tailings underlying the thickened tailings. This delayed the process of monitoring of ongoing consolidation through collection of samples of the paste/thickened tailings, and installation of piezometers. However, visual evidence of drying (e.g. dessication cracking) of exposed surfaces of inactive areas of deposition cells began to appear in some areas in mid-2011 and were very prevalent in those inactive areas through the dry period (April to September) of 2012, when tailings surfaces rose to elevations in the order of 2-3 $\mathrm{m}$ above the pond level outside the cells.

In 2012 Somincor completed a new LOM Plan based on additional proven reserves, which will require a vertical expansion of the IRCL expansion relative to the Figure 2 configuration related to the 2005 LOM Plan. Golder Associates has therefore been commissioned to evaluate the feasibility of stacking additional paste at the IRCL to elevations of the order of $275 \mathrm{~m}$, or some $20 \mathrm{~m}$ above existing perimeter dams. The high seismicity of the site ( $0.26 \mathrm{~g}$ maximum design acceleration) will be the primary limiting factor in this regard.

Within this context a campaign of CPTu with pore pressure measurements and collection of piston samples of paste and underlying slurry tailings was carried out in the summer of 2012 to provide in situ strength and permeability data as well as evaluation of the 'state parameter' (a soil behaviour index, Been and Jefferies, 1985 ) of the deposited tailings. This type of data and a planned special laboratory testing program will be used to calibrate a model of the evolution of the void ratio of the deposit as a function of time and of additional deposition loads. This model and continued operational monitoring will guide the design of the final deposition landform.

While this work is ongoing and will likely be reported in more detail at future technical conferences, a brief summary of the preliminary conclusions from the CPTu campaign regarding the degree of consolidation of paste and underlying tailings in mid-2012 is given here.

\subsubsection{Degree of consolidation of the tailings}

The consolidation of the tailings depends on $c_{h}$ (the coefficient of consolidation). This coefficient has been measured using dissipation tests during the CPTu soundings, evaluated using the Teh and Houlsby (1991) framework. The measured data is shown in Figure 16, with the two types of tailings (paste and subaqueous) distinguished; there is substantial overlap in the range of $c_{h}$ across all 'soil' types.

The paste shows a range $4 \times 10^{-6} \mathrm{~m}^{2} / \mathrm{s}<c_{\mathrm{h}}<1 \times 10^{-4} \mathrm{~m}^{2} / \mathrm{s}$. The segregated subaqueous tailings show $8 \times 10^{-6}$ $\mathrm{m}^{2} / \mathrm{s}<c_{\mathrm{h}}<1 \times 10^{-4} \mathrm{~m}^{2} / \mathrm{s}$ with a distinct clustering around $c_{\mathrm{h}} \approx 2 \times 10^{-5} \mathrm{~m}^{2} / \mathrm{s}$. It appears that both tailings materials are controlled by their silt fraction, and that the entrained sand in the paste is insufficient to form sand-to-sand particle contacts.

The CPTu dissipation tests were also used to observe the progress of consolidation in the tailings, as the end-of-dissipation pressures measures the current in situ pore pressure. The data is shown in Figure 17. In the case of subaqueous tailings, excess pore pressures range from zero (a hydrostatic condition) in cell locations where filling was stopped for over a period of three to eight months prior to the CPTu, to values as high as $100 \mathrm{kPa}$ in the tailings below a recently constructed dyke. In the case of the paste, excess pressures exist in areas of recent deposition but are only about $10-20 \mathrm{kPa}$; of course the paste is thin, less than $5 \mathrm{~m}$, so these excess pore pressures represent a substantial degree of under-consolidation.

The measured $c_{\mathrm{h}}$ values can be used to develop an expected time for 'consolidation', here taken as a dimensionless time factor of unity. The piezometric data establishes that the base of the tailings impoundment is relatively impervious, with upward drainage predominating. For the common $15-25 \mathrm{~m}$ thickness of tailings in the impoundment, consolidation times should be about six months to perhaps a year; this affects the paste as the paste loads the underlying slurry tailings and the upward migration of pore water retards the consolidation of the paste. 


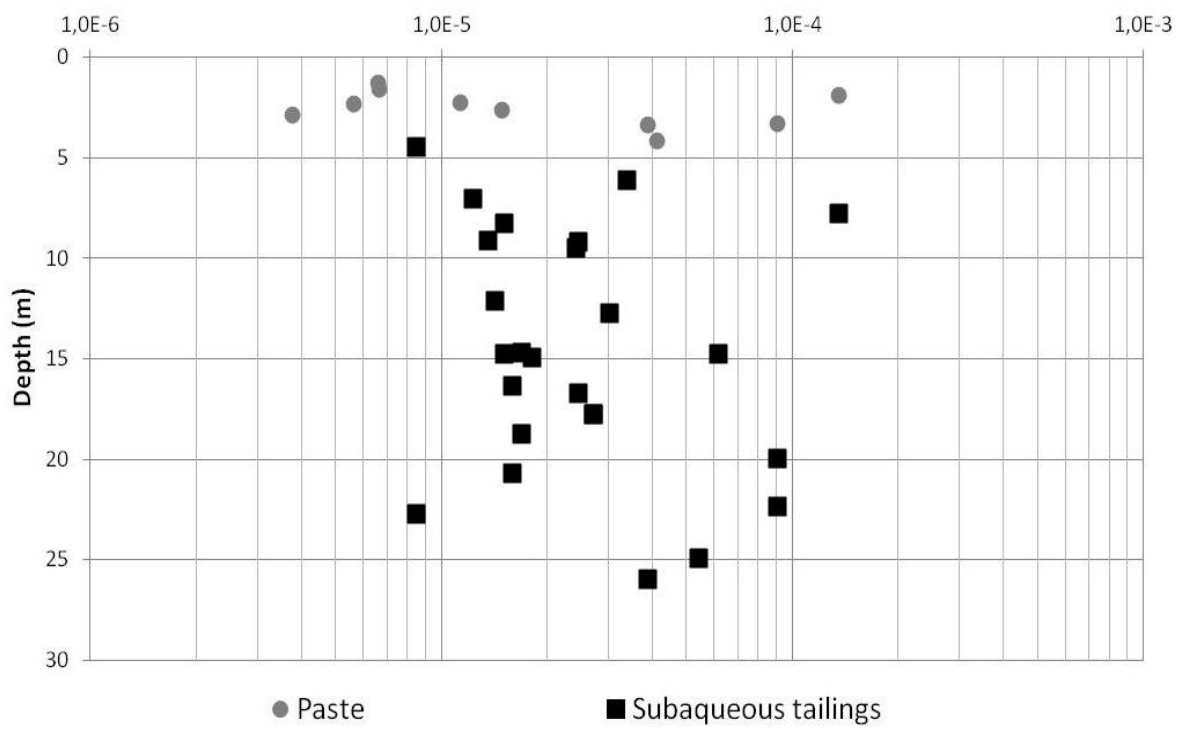

Figure 16 Coefficient of consolidation versus depth, based on CPTu testing
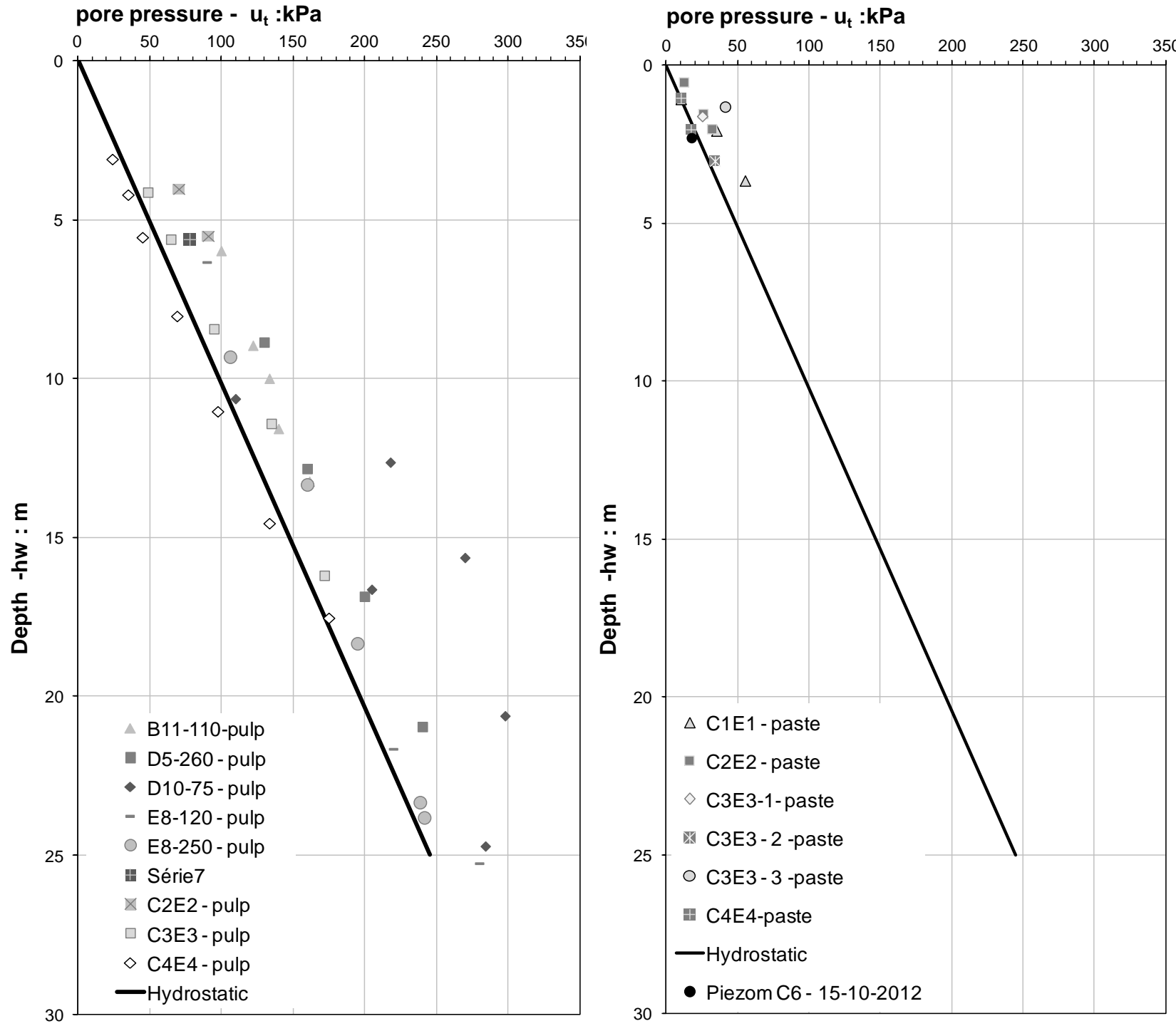

Figure 17 Measured pore pressures versus depth 


\subsection{Monitoring of oxidation of inactive tailings surfaces}

A routine testing program has been implemented to verify the premise amount that the non-segregated nature of thickened/paste tailings and resulting higher moisture content retention significantly slows oxidation rates of the subaerial deposit (Verburg et al., 2009).

The testing program basically consists of obtaining cores of the top one metre of deposited tailings material, at one week intervals, in selected inactive areas. The cores are then tested for porewater $\mathrm{pH}$ at selected vertical intervals, which range from $25 \mathrm{~mm}$ in the top $100 \mathrm{~mm}$ of the exposed tailings to $600 \mathrm{~mm}$ in the lower section of the one metre profile. The results are shown graphically on Figure 18.

Taking $\mathrm{pH}=7$ as a reference, the test results show that oxidation was detectable generally only in the top $50 \mathrm{~mm}$ of each one metre layer tested. In addition the minimum $\mathrm{pH}$ recorded was in the range of 6 for surface samples obtained by scraping. On this basis it is concluded that the deposition and drying cycles and the filling control achievable in the cells has been adequate to maintain the environmental stability of the deposit.

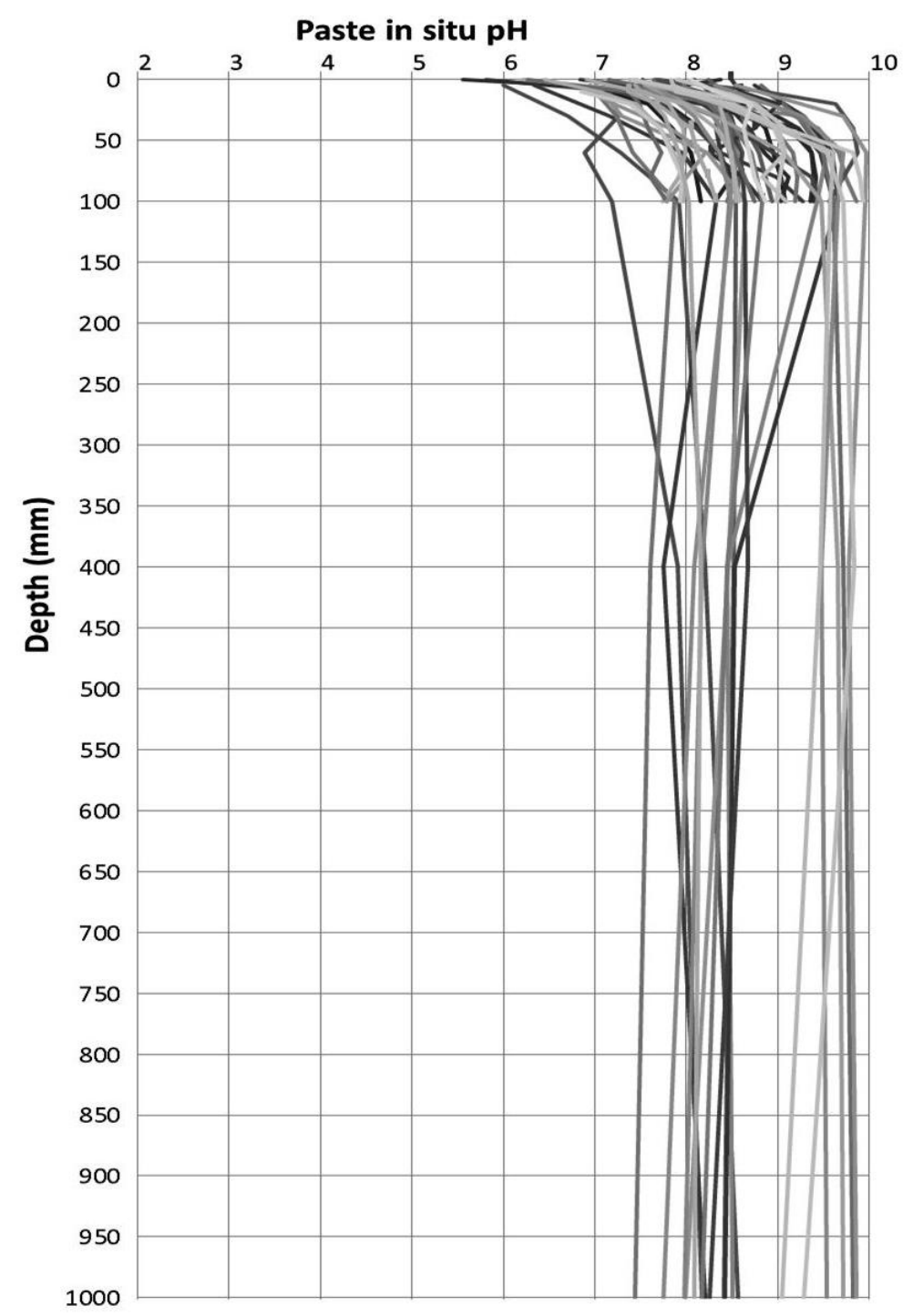

Figure $18 \quad 2012$ summer in situ paste oxidation control

\section{Conclusions}

The Neves Corvo mine TMF has been converted from subaqueous deposition of slurried tailings to subaerial deposition of thickened/paste tailings. The deposition of thickened/paste tailings into ponded water and 
onto a layer of unconsolidated subaqueous tailings significantly delayed consolidation and drying of the first 2-3 m of deposited paste. Based on field observations it is believed that drying effects on tailings density are beginning to increase as the deposit rises.

The tailings feed to the thickening plant (TMF paste plant) is variable on a daily (and possibly hourly) basis, both in terms of solids flow rate and PSD. Although the paste plant has a homogenising capability in terms of PSD characteristics of its product (underflow) the per cent solids and yield stress of the tailings discharged to the deposition area show significant variation, with consequent effects on beach slope and initial in situ density. The deposited thickened tailings are however non-segregating, as per environmental design requirements, and routine $\mathrm{pH}$ testing to date shows that current cell deposition and drying cycles are adequate to control oxidation of the deposit.

A study is underway regarding the feasibility of stacking an additional $15 \mathrm{~m}$ of paste tailings above currently approved elevations, which are only about $4 \mathrm{~m}$ above the perimeter dams. Preliminary results indicate that tailings consolidation is occurring simultaneously with the continuous application of load from ongoing tailings deposition. Continued field monitoring, laboratory testing and modelling work are needed to design the final IRCL landform.

\section{Acknowledgements}

The authors would like to thank Somincor's management for approval of publication of this paper. Thanks are also due to Ana Rodrigues who contributed all data processing and figures for the paper.

\section{References}

Been, K. and Jefferies, M.G. (1985) A state parameter for sand, Geotechnique, Vol. 35, pp. 99-112.

Junqueira, F., Wilson, G. and Oliveira, M. (2009) Surface paste disposal of high-sulphide tailings at Neves Corvo Mine in Portugal, Part 1: Estimation of tailings desaturation and implications on ARG generation, in 8th International Conference on Acid Rock Drainage (ICARD) and Security, the Future: Mining, Metals and the Environment in a Sustainable Society 2009, Curran Associates, Inc. (ed), 22-26 June, Sweden, Skelleftea, Vol. 1, p. 1046.

Kam, S., Girard, J., Hmidi, N., Mao, Y. and Longo, S. (2011) Thickened tailings disposal at Musselwhite Mine, in Proceedings 14th International Seminar on Paste and Thickened Tailings (Paste2011), R.J. Jewell and A.B. Fourie (eds), 5-7 April 2011, Perth, Australia, Australian Centre for Geomechanics, Perth, pp. 225-236.

Li, A.L., Been, K., Ritchie, D. and Welch, D. (2009) Stability of large thickened, non-segregated tailings slopes, in Proceedings 12th International Seminar on Paste and Thickened Tailings (Paste09), R.J. Jewell, A.B. Fourie, S. Barrera, J. Wiertz (eds), 21-24 April 2009, Viña Del Mar, Chile, Gecamin Limited, Santiago, Australian Centre for Geomechanics, Perth, pp. 301-312.

Oliveira, M., Falé, P. and Rodrigues, A. (2011) Surface paste disposal of high-sulphite tailings part 1 - Construction of cells, in 22nd World Mining Congress and Expo 2011, Aydoğdu Ofset (ed), 11-16 September 2011, Turkey, Vol. II, p. 365.

Roussel, N. and Coussot, P. (2004) "Fifty-cent" rheometer for yield stress measurements: From slump to spreading flow, Journal of Rheology, Vol. 49, pp. 705-718

Teh, C.I. and Houlsby, G.T. (1991) Analytical study of the cone penetration test in clay, Geotechnique, Vol. 41, pp. 17-34.

Theriault, J., Frostiak, J. and Welch, D. (2003) Surface disposal of paste tailings at the Bulyanhulu Gold Mine, in Proceedings Sudbury 2003 Mining and the Environment, G. Spiers, P. Beckett, and H. Conroy (eds), 25-28 May 2003, Sudbury, Canada, pp. 265269.

Verburg, R., Ross, C. and Oliveira, M. (2009) Surface paste disposal of high-sulphite tailings at Neves Corvo Mine in Portugal, Part 2: Field trial cover performance monitoring and impact assessment, in 8th International Conference on Acid Rock Drainage (ICARD) and Security, the Future: Mining, Metals and the Environment in a Sustainable Society 2009, Curran Associates, Inc. (ed), 22-26 June 2009, Sweden, Skelleftea, Vol. 1, p. 1056. 
Thickened and Paste Tailings 